University of Nebraska - Lincoln

DigitalCommons@University of Nebraska - Lincoln

Faculty Publications: Department of Entomology

1995

\title{
Population Genetics and Gene Variation in Secondary Screwworm (Diptera: Calliphoridae)
}

\author{
David B. Taylor \\ University of Nebraska-Lincoln, dave.taylor@ars.usda.gov \\ Richard D. Peterson II \\ University of Nebraska-Lincoln, padr20@yahoo.com
}

Follow this and additional works at: https://digitalcommons.unl.edu/entomologyfacpub

Part of the Entomology Commons

Taylor, David B. and Peterson, Richard D. II, "Population Genetics and Gene Variation in Secondary Screwworm (Diptera: Calliphoridae)" (1995). Faculty Publications: Department of Entomology. 208. https://digitalcommons.unl.edu/entomologyfacpub/208

This Article is brought to you for free and open access by the Entomology, Department of at DigitalCommons@University of Nebraska - Lincoln. It has been accepted for inclusion in Faculty Publications: Department of Entomology by an authorized administrator of DigitalCommons@University of Nebraska - Lincoln. 


\title{
Population Genetics and Gene Variation in Secondary Screwworm (Diptera: Calliphoridae)
}

\author{
DAVII) B. TAYLOR ANI RICHARD D. PETERSON II
}

Midwest Livestock Insects Research Laboratory, USIDA-ARS, Department of Entomology, University of Nebraska, Lincoln, NE $68.58,3$

Am. Entornol. Soc. Am. 88(5): 690-694 (1995)

\begin{abstract}
Allozyme variation in 4 populations of secondary screwworm, Cochliomyia macellaria (F.), representing North, Central, and South America was examined. Variability was observed in 12 of 13 enzyne loci, and the frequency of the most common allele was $<0.95$ for 6 loci. Observed and expected heterozygosities were 0.149 and 0.154 , respectively. Nei's genetic distances were $\leq 0.001$. Coodness-of-fit statistics for I Iardy-Weinberg eefuilibrium and Wright's $F_{\text {IS }}$ statistics indicated random mating within populations. Wright's $F_{\text {ST }}$ statistics and chi-square contingency analyses indicated homogeneous gene frequencies among the populations. These data suggest that $C$. macellaria is a panmictic species with high levels of gene flow between populations.
\end{abstract}

KEY WORDS Cochliomyia macellaria, population genetics, isozymes

BLOW FLIES AKE among the earliest recognized insect plagues of mankind. Many species are associated with dermal and secondary traumatic myiasis, and a few species are agents of primary trammatic myiasis (Hall 1948). In addition to their propensity to infest wounds and "blow" meats, the attraction of blow flies to proteinaceous foods, including feces, garbage, fresh meats, and cheeses, has implicated them as vectors of filth-related diseases such as bacterial and amoebic dysentery, anthrax, and cholcra (Hall 1948). Blow flies are also considered important indicators for time of death in forensic entomology (Creenberg 1991, Catts and Goff 1992). Despite their ubiquitous nature and conomic importance, little is known concerning genetic variation within and between blow fly populations. Limited data exist on isoryme variation in the 2 species of primary screwworms, Chrysomya bezziana Villenenve (Strong and Mahor 1991) and Cochliomyia hominivorax (Coquerel) (Taylor and Peterson 1994). However, other than Taylor and Peterson's (1994) study of Cochliomyia macellaria (F.) from northwestern Costa Rica, no information exists on the population structure of a saprophagous blow fly species.

Secondary screwworm, Cochliomyia macellaria, is a highly variable and widespread species. Thirtytwo synonyms for this species have been published, including 9 by Robincau-Desvoidy alone? (Dear 1985). C. macellaria is distributed throughout the New World from Canada to Argentina and the (aribbean (Dear 1985). C. macellaria is a sibling species to the primary New World screwworm, C. hominivorax. Although morphologically similar, C. hominioorax and C. macellaria are behaviorally very different. C. hominivorax is an obligate parasite of wounds of warm-blooded vertebrates, whereas C. macellaria is primarily saprophagous (I jake et al. 19.36).

Our study was conducted in conjunction with studies of $C$. hominivorax population st ructure. We presume that the population structure of C. macellaria is representative of saprophagous blowtlies and represents the ancestral state from which $C$. hominivorax was derived. By studying the similarities and differences between these 2 species, we hope to gain insight into the evolution and biology of parasitism in blow Hies. The specific purpose of this study was to examine genetic variation in geographically distant populations of C. macellaria.

\section{Materials and Methods}

Specimens. Adult C. macellaria wero collected from rotting liver, animal carcasses, or calves infested with $C$. hominivorax. Flies were collected from I incoln, NE, in August 1993 (US), 3 sites in northwestern Costa Rica (CR) (Taylor and Peterson 1994), Tuxtla Gitierre\%, Chiapas, Mexico, in August 1993 (MEXICO), and Seropedica, Rio de Janeiro, Brazil, in March 1994 (BRAZII.). Flies were stored in liquid nitrogen or at $-80^{\circ} \mathrm{C}$ until used for the isoryme analysis.

Electrophoretic Techniques. Polyacrylamide gel electrophoresis was used for this study. Technicues were the same as those reported by Taylor and Peterson (1994). The head was removed from each fly and stored individually for use in future molecular genetic studies. Decapitated flies were ground in $150 \mu \mathrm{l}$ of grinding buffer composed of 
Tabble 1. Gene diversity at enzyme loci in $C$. macellaria

\begin{tabular}{|c|c|c|c|c|c|}
\hline Enжyme & E.C. no. ${ }^{t}$ & Symbol" & No. alleles & $\mathrm{HI}_{i} 6$ & $\mathrm{II}_{e^{d}}$ \\
\hline Aconitato livelratase. & 4.2 .1 .3 & AC:OIf & 6 & 0.187 & 0.200 \\
\hline Formaldehyde dehydrogemase & 1.2 .1 .1 & $\mathrm{FDHI}$ & 6 & 0.088 & 0.088 \\
\hline Fructose-biphosphate aldolase & 4.1 .2 .13 & $A[, I)$ & 1 & 0.000 & 0.000 \\
\hline Fiumarate liydratase & 4.2 .1 .2 & FUMH & 2 & 0.004 & 0.004 \\
\hline Glyceraldeliyde-3-phosphate dehydrogemase & 1.2 .1 .12 & GAPIII & 2 & 0.002 & 0.002 \\
\hline Glycerol de hydrogenase & 1.1 .1 .72 & (;) (X) & 8 & $0.40: 3$ & 0.414 \\
\hline Glycerol-3-phosphate dehydrogenase & I.1.1.8 & $\left(: 3 P^{\top}\right) \mathrm{II}$ & 3 & 0.009 & 0.009 \\
\hline Hydroxyacid dehydrogenatse & 1.1 .99 .6 & $\|A\| \|$ & 6 & 0.175 & 0.170 \\
\hline Isocit rate deloydrogentise. & 1.1 .1 .42 & 11311 & 4 & 0.0 .53 & 0.0 .51 \\
\hline Maldate dehyclogenase & 1.1 .1 .37 & МDH & 4 & 0.015 & 0.015 \\
\hline Mantuese-6-phosphate isomeraso & 5.3 .1 .8 & MPI & 10 & 0.614 & 0.645 \\
\hline Phesploorlucomate 2-dehydrogenase & 1.1.1.4.4 & PC:DH & 6 & 0.192 & 0.207 \\
\hline Phosphoghlucomutase & 5.4 .2 .2 & $P C: M$ & 5 & 0.195 & 0.196 \\
\hline $\mathrm{M}$ CaII $+\mathrm{SEM}$ & & & $5.08 \pm 0.72$ & $0.149 \pm 0.051$ & $0.154 \pm 0.053$ \\
\hline
\end{tabular}

"Nomenclature Committes lutermational Union of Biochemistry 1984.

b Murphy of al. (1990).

colserved heteromgesity

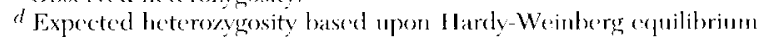

$10 \%$ sucrose, 0.1\% Triton X-100 (Sigma, St. Louis, MO), $0.37 \%$ EIJTA, bromophenol blue and morcaptoethanol in 1:5 dilute Tris-citrate (TC) buffer (19 $\mathrm{mM}$ Trimma base [Sigma Chemical Co.], 5.6 mM citric acid, pH 7.1). Electrophoresis condi. tions were $6 \%$ polyacrylamide gels $(14$ by $16 \mathrm{~cm}$ and $1.5 \mathrm{~mm}$ thick) run at $300 \mathrm{~V}$ constant voltage for 3 h with Tris Borate FIDT (TBE) buffer ( 8 I $\mathrm{mM}$ Trima base, $28 \mathrm{mM}$ boric acid, $14.6 \mathrm{mM}$ EDTA, pH 8.9) or $4 \mathrm{~h}$ with TC: buffer in vertical slab gel mits (Ilocffer Scientific, San Francisco, CA). Initial currents were 0.027 (TBE) and (0.045 (TC) $\mathrm{mA}$ per gel, and ending currents were 0.015 (TBE) and 0.039 (TC) $\mathrm{mA}$ per gel. Buffer in the TC units was circulated between the upper and lower chambers to avoid overheating. Staining procedures, recipes, and allele nomenclature were the same as those used by Taylor and Peterson (1994). Thirteen enzyme systems were used for this study (Table 1).

Statistical Analysis. BIOSYS-1 (Swofford and Selander 1981) was used to compute population allele frequencies, expected and observed heterozygosities, test for fit with IIardy-Weinberg expectations, and calculate Nei's genetic distance (Nei 1978 ) and Wright's $F$ statistics (Wright 1978). Significant deviation from zero of Wright's $F_{\mathrm{ST}}$ and $F_{\mathrm{TT}}$ statistices was determined by calculating chi-square statistics with the following formulas $\chi^{2} F_{\mathrm{ST}}=2 \mathrm{~N}$ $\left(F_{\mathrm{ST}}\right)(k-1)$ with $(k-1)(s-1)$ df and $\chi^{2} F_{\mathrm{rT}}=$ $\left(F_{\mathrm{I}^{\mathrm{T}}}\right)^{2} \mathrm{~N}(k-1)$ with $k(k-1)$ df for $k$ alleles and $s$ populations. Chi-square contingency analysis with a Yates adjustment for small expected frequencies was used to compare allele frequencies between populations. Flies from the i3 collections in Costa Rica were pooled for comparison with the other collections.

\section{Results}

Twelve of 13 isozyme loci were variable and 6 were polymorphic (frequency of most common al- lele <0.95) (Table 2). Expected and observed heterozygosities were 0.149 and 0.154 , respectively. A mean of 5.08 alleles per locus was observed. Observed genotypes did not differ significantly from Hardy-Weinberg expectations (with pooling, see Swofford and Selander [1981], $P<0.05)$ except for $P g d$ in the US collection (excess homorygotes, $\chi^{2}=15.284$, df $\left.=1, P<0.001\right)$.

Wright's $F$ statistics suggested little departure from random mating in $C$. macellaria populations. Among the individual locus $F_{\text {ST }}$ and $F_{\text {IT }}$ values, only $F_{\mathrm{ST}}$ for $M p i$ differed significantly from zero (Table 3). The moan $F_{S T}$ value, 0.007 , indicated that geographic differentiation accounts for $<1 \%$ of the observed genetic variability. In fact, of the 65 alleles examined, frequencies among populations varied significantly only for the 112 allele of Acoh (Table 2). Overall allele frequencies did not differ among populations for any of the 13 loci studied and the total chi-square value, 94.287 (df $=159$ ), was not significant. Nei's unbiased genetic distances were $\leq 0.001$ (Table 4 ).

\section{Discussion}

The level of genetic variability observed in $C$. macellaria is similar to that observed in other cycorrhaphous Diptera: Musca autumnalis De Geer $\left(H_{c}=0.18\right.$ [Krafsur and Black 1992]), Musca domestica I. $\left(H_{\mathrm{c}}=0.11\right.$ [Black and Krafsur 1985]), Haematobia irritans $(\mathrm{L}).\left(H_{\mathrm{e}}=0.14\right.$ / McDonald et al. 1987]), Stomoxys calcitrans (L.) $\left(H_{+}=0.09\right.$ [ Krafsur 1993]), and Cochliomyia hominivorax ( $H_{\mathrm{c}}$ $=0.14$ [Taylor and Peterson 1994]). However, unexpectedly low levels of genetic differentiation among geographically distant populations were observed in C. macellaria. Comparable studies of insect species across such a broad geographic range are few. Munstermann (1980, 1984) reported genetic distances of $0.12-0.23$ for populations of $\mathrm{Ae}$ des epactius Dyar and Knab distributed from Utah to El Salvador and $0.00-0.05$ for $A$. triseriatus 
Table 2. Nllele frequencies for variable isongme locei in C. macellaria

\begin{tabular}{|c|c|c|c|c|c|c|}
\hline Ix) & $\begin{array}{l}\Delta \mathrm{l} \\
\text { ledc }\end{array}$ & $\begin{array}{l}\text { Bnited } \\
\text { States }\end{array}$ & Mexicen & $\begin{array}{l}\text { Cosstit } \\
\text { Ricat }\end{array}$ & Brazil & $x^{2+t}$ \\
\hline \multirow[t]{8}{*}{ Aroh n $n^{b}$} & & 100 & 50 & 252 & (s) & \\
\hline & 100 & 0.00 .5 & 0.010 & 0.002 & 0 & 0.185 \\
\hline & 105 & 0.00 .5 & () & 0.004 & 0 & 0.155 \\
\hline & 112 & 0.05 .5 & 0 & 0.0 .1 .4 & 0.0331 & 10.336 \\
\hline & 116 & 0.065 & 0.060 & $0.05: 3$ & 0.056 & 0.192 \\
\hline & 120 & 0.8 .10 & 0.920 & 0.597 & $0.91: 3$ & 0.696 \\
\hline & 121 & 0 & 0.010 & 0 & 0 & 2.129 \\
\hline & $x^{2}$ & 6.45:3 & 5.736 & 0.092 & $0.9) 1 . t$ & $1.3 .724^{d}$ \\
\hline \multirow[t]{8}{*}{$F_{i} / h, n^{\prime}$} & & 100 & 50 & $2 \times 2$ & 100 & \\
\hline & $8+$ & 0.000 & 0.010 & 0.001 & $0.0(10)$ & 0.157 \\
\hline & 100 & 0.020 & 0.030 & $0.02 \geq 0$ & 0.010 & 0.0 .51 \\
\hline & 105 & 0.005 & 0 & 0.001 .4 & 0 & 0.271 \\
\hline & 111 & $0.95 \overline{5}$ & 0.920 & 0.952 & 0.950 & $0.7: 30$ \\
\hline & $1: 32$ & 0.020 & 0.0330 & $(0.0) 21$ & 0.010 & 0.205 \\
\hline & 145 & 0 & 0.010 & 0 & 0 & 2.128 \\
\hline & $x^{2}$ & 0.219 & 2.3 .19 & 0.0992 & $0.91+t$ & $3.573^{\prime \prime}$ \\
\hline \multirow[t]{4}{*}{ Fumh $n^{\prime \prime}$} & & 100 & 50 & $2 x \geq 2$ & 100 & \\
\hline & $106 j$ & 1.000 & 1.000 & 0.996 & $1.000)$ & 0.001 \\
\hline & 153 & 0 & 0 & 0.004 & 0 & 0.152 \\
\hline & $x^{2}$ & 0.041 & 0.13 is & 0.183 & 0.0 .11 & $0.1 .53^{d}$ \\
\hline \multirow[t]{4}{*}{ Galprllo, $n^{h}$} & & 100 & 50 & 252 & 100 & \\
\hline & $I 0(0)$ & 1.000 & 1.0000 & 0.995 & 1.000 & $0.000)$ \\
\hline & 114 & 0 & () & $0 .(1)(2)$ & 0 & 0.472 \\
\hline & $x^{2+}$ & 0.185 & 0.094 & 0.0102 & 0.185 & 0.472. \\
\hline \multirow[t]{10}{*}{ Cad $n^{b}$} & & 100 & 17 & 262 & 97 & \\
\hline & $: 36$ & 0.025 & 0.0 .53 & 0.035 & 0.0365 & 0.7 .2 \\
\hline & 47 & 0.0 .20 & 0 & 0.0 .20 & 0.015 & 0.5 .50 \\
\hline & 53 & 0.005 & () & 0.000 & () & 0.564 \\
\hline & $6 .+$ & 0.795 & $0 . \bar{s} \bar{i}$ & 0.75 & 0.7 .12 & 1. 126 \\
\hline & 77 & 0.005 & () & 0.011 & $0.0] 0$ & 0.511 \\
\hline & 90 & 0.145 & 0.160 & 0.206 & 0.191 & 2.865 \\
\hline & 100 & 0 & 0 & 0.002 & 0 & 0.165 \\
\hline & 116 & 0.0105 & () & 0 & 0.010 .5 & 0.560 \\
\hline & $x^{2}$ & 3.1 .40 & 2.161 & 2.771 & 0.575 & $5.6 .51^{d}$ \\
\hline \multirow[t]{5}{*}{$(: 3) / h, n^{h}$} & & 100 & 50 & 282 & 100 & \\
\hline & 7.4 & 0.00 .5 & 0.010 & 0.0002 & $0.0(0) 5$ & 0.356 \\
\hline & 100 & 0.900 & $0.990)$ & 0.495 & 0.995 & 0.001 .1 \\
\hline & 117 & 0.0105 & () & 0 & 0 & 0.801 \\
\hline & $x^{2 i}$ & $0.60) 1$ & 0.13 .5 & $0.15 \overline{5}$ & 0.270 & $1.191^{d}$ \\
\hline \multirow[t]{8}{*}{ Hadhe, $u^{\prime}$} & & 100 & 50 & 242 & 9 & \\
\hline & $y$ & $0.0(15)$ & 0 & () & 0 & 0.800 \\
\hline & 96 & 0.015 & 0.030 & 0.021 & 0 & 3.212 \\
\hline & 108 & $0 . \$ \$ 5$ & 0.940 & 0.904 & $0.93-1$ & 0.998 \\
\hline & 125 & 0.050 & 0.0 .30 & 0.06 .4 & 0.066 & 1.856 \\
\hline & 130 & () & 0 & 0.0002 & 0 & 0.170 \\
\hline & 112 & 0.015 & 0 & $0.00 \mathrm{~s}$ & 0 & 1.11 .1 \\
\hline & $x^{2 x}$ & $2.0: 38$ & 2.042 & $0 .+25$ & 3.572 & $8.07 \%$ \\
\hline \multirow[t]{6}{*}{$l d h \cdot n^{h}$} & & 100 & 50 & 282 & 100 & \\
\hline & 93 & 0.005 & 0 & 0 & 0 & 0.502 \\
\hline & 100 & 0.965 & 0.490 & 0.966 & 0.995 & 0.118 \\
\hline & 117 & $0.0 .30)$ & 0.010 & 0.0 .34 & 0 & $5.9(95)$ \\
\hline & 129 & 0 & 0 & 0 & 0.005 & 0.509 \\
\hline & $x^{2}$ & 0.791 & 0.5666 & 1.64 .4 & 4.717 & 7.717 \\
\hline \multirow[t]{7}{*}{$M\left(l h, n^{h}\right.$} & & 100 & 50 & 282 & 100 & \\
\hline & 59 & 0 & 0 & 0.002 & 0 & 0.172 \\
\hline & 92 & 1.000 & 1.000 & $0.98 \mathrm{~s}$ & 0.995 & 0.015 \\
\hline & 109 & 0 & 0 & 0.00 .4 & 0.005 & 0.188 \\
\hline & 11.4 & 0 & 0 & 0.005 & 0 & 0.70 .1 \\
\hline & 121 & 0 & 0 & 0,000 & () & 0.472 \\
\hline & $x^{2}$ & 0.3966 & 0.526 & 0.538 & 0.3491 & $1.850 y$ \\
\hline \multirow[t]{6}{*}{$M p i, n^{\prime}$} & & 100 & 50 & 282 & 97 & \\
\hline & 9.1 & 0.005 & 0 & 0.004 & 0.010 & 0.386 \\
\hline & 108 & (). 215 & $0.1: 30$ & 0.156 & (1).1.1.t & 3.938 \\
\hline & 112 & 0.010 & 0 & 0.032 & 0.021 & 1.0 .26 \\
\hline & 12.1 & 0.080 & 0.110 & 0.108 & $0.0 .+1$ & 6.780 \\
\hline & $1: 30$ & 0.005 & 0 & 0 & 0 & 0.787 \\
\hline
\end{tabular}

Table 2. Continued

\begin{tabular}{|c|c|c|c|c|c|c|}
\hline I cocens & $\begin{array}{l}\mathrm{Al} \\
\mathrm{l} \cdot \mathrm{l}\end{array}$ & $\begin{array}{l}\text { Inited } \\
\text { Statess }\end{array}$ & Mexico & $\begin{array}{l}\text { Costit } \\
\text { Rirail }\end{array}$ & Bratzil & $x^{2 i}$ \\
\hline & 7.40 & 0.50 .5 & (0. 6330 & 0.523 & $0,63 . t$ & 4.715 \\
\hline & 1.55 & 0.010 & 0 & 0 & 0 & 3.868 \\
\hline & 160 & 0.135 & 0.100 & 0.1 .55 & $0.0 \mathrm{ss}$ & 3.791 \\
\hline & $1 \mathrm{so}$ & 0.005 & 0.010 & 0.012 & 0.010 & 0.232 \\
\hline & 199 & $0.0: 30$ & $0.0+20$ & 0.090 & 0.052 & 4.324 \\
\hline & $x^{2 x}$ & +.950 & 3.545 & 6.453 & 13.214 & $25.192^{d}$ \\
\hline \multirow[t]{8}{*}{$r^{\prime}\left(s m, n^{b}\right.$} & & 100 & 50 & $282 \underline{2}$ & 100 & \\
\hline & 85 & 0 & 0 & 0.002 & 0.010 & 1.734 \\
\hline & 91 & 0.045 & 0.050 & 0.0 .30 & 0.070 & 1714 \\
\hline & 9.1 & 0.020 & 0.010 & 0.011 & 0.015 & (). 1333 \\
\hline & 100 & 0.595 & 0.590 & 0.908 & 0.560 & 0.326 \\
\hline & los & 0.0 .40 & 0.050 & $0.0 .1 \mathrm{~s}$ & 0.0353 & 0.317 \\
\hline & 11.4 & 0 & 0 & 0.002 & 0.010 & 1.734 \\
\hline & $x^{2 x}$ & $0,31+4$ & 0.382 & 2.011 & 6.551 & 9.258 \\
\hline \multirow[t]{9}{*}{$P \log l h, n^{l}$} & & 100 & 50 & 282 & 100 & \\
\hline & 60 & 0.005 & 0 & 0 & 0 & 0.801 \\
\hline & 100 & 0.020 & 0 & 0.016 & 0.010 & 0.825 \\
\hline & 117 & 0.570 & $(0.930)$ & $0.5 \% 1$ & 0.920 & 0.511 \\
\hline & 133 & 0.015 & 0 & 0.012 & 0.010 & 0.405 \\
\hline & $1+12$ & 0.065 & 0.060 & 0.0533 & 0.050 & 2063 \\
\hline & 167 & 0.00 .5 & 0.010 & 0.012 & 0 & 1.516 \\
\hline & 186 & 0.020 & 0 & 0.002 & 0.010 & 5005 \\
\hline & $x^{2 n}$ & 1.417 & 1.316 & 3.0 .40 & 2.326 & $11.128^{d}$ \\
\hline
\end{tabular}

$*, y<0.05$

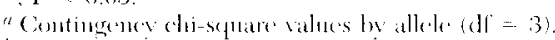

1) Vumber of individuats cximined from eatele perpulation.

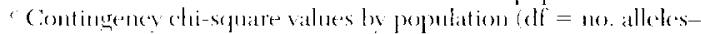

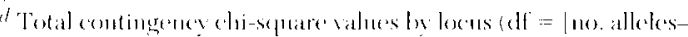
1) $\times 33$.

(Say) populations from northern Michigan to southern Texas. Tabachunck and Powell (1979) reported a mean genetic distance of 0.0149 between New World populations of Aedes aegypti (L.). Bartlett et al. (198:3) observed genctic distances of $0.017-0.508$ among populations of boll weevil, Anthonomus grandis grandis Boheman, from the United States and Mexico. Steck (1991) Cound genetic distances botween 0.05 and 0.137 between populations of the tephritid Anastrepha fraterculus (Wiedemann) from Brazil, Venezuela, Costa Rica,

Talle 3. Wright (1978) $F$ statisties for $C$. macellaria populations

\begin{tabular}{|c|c|c|c|}
\hline I acus & $\mathrm{F}_{15}$ & $\mathrm{Fsl}_{\mathrm{si}}$ & $\mathrm{F}_{\text {IT }}$ \\
\hline Acoll & $0.07,3$ & 0.010 & 0.082 \\
\hline Foll & -0.0 .31 & 0.006 & -0.02 .1 \\
\hline Flumh & $-0.00) .4$ & 0.003 & $\cdots-0.00]$ \\
\hline Cattulle & 0.0002 & 0.001 & $0.14)(x$ \\
\hline Cird & 0.014 & 0.005 & 0.010 \\
\hline$(: 3) \mathrm{dh}$ & $-0.0(0) 8$ & $0.0(1) 2$ & $\cdots 0.006$ \\
\hline IIrill & 0.039 & 0.006 & -0.0332 \\
\hline$l d l$ & 0.020 & $0.0(x)$ & $-0.0 \mid 9$ \\
\hline $\mathrm{Md} / \mathrm{t}$ & -0.007 & $0.00)+$ & -0.0003 \\
\hline$M p i$ & 0.013 & $0.010^{*}$ & 0.0 .2 \\
\hline$P_{m}^{\prime} m$ & $0.00 \mathrm{5}$ & $0.000 ; 3$ & 0.005 \\
\hline$P_{w}(r / h$ & 0.055 & 0.006 & 0.098 \\
\hline Mratl & 0.018 & $0.00)^{-}$ & 0.02 .5 \\
\hline
\end{tabular}


Table 1. Neips unbiased genetio distancen for C. mecellaria

\begin{tabular}{|c|c|c|c|c|}
\hline Ix ax"ation & 1 & 2 & 3 & 4 \\
\hline 1 Cinted States & 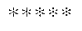 & 0.001 & 0.0000 & 0.001 \\
\hline 2 Mexicos & & $* * * * *$ & 0.001 & 0.0000 \\
\hline 3 Cossta Ricat & & & 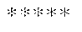 & 0.001 \\
\hline 4 Brwil & & & & 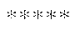 \\
\hline
\end{tabular}

and Mexico. In the only other spereses of blow fly for which iscryme data are available. Strong and Mathom (1991) obtained genetic distances as large as 0.098 botween populations of C. beraiana from southem Africa, the Middle East. Malassia, Indonesial, and Palpua New Gumeat. All of these values are an order of magnitude greater than the largest genetic distance. 0.001 , observed between popenlattions of (C. macellaria.

Blow flies are strong-llying insects. (.) hominicorax has beren reported to fly as far as $290 \mathrm{~km}$ in 2 wh (IIightower et al. 1965), although normal lifetime dispersal is probably within the range of :3$25 \mathrm{~km}$ (Maver and Atzoni 1993). The reliance of blow flies on patchy and ephemeral larval habitats requires females to disperse widely in scatrch of oviposition sites. Because corpses are usually colonized by many females from diverse origins, the level of gence How is potentially high. This dispersion and intermixing in cach generation is probably responsible for the homogenesty of $C$. macellaria populations (Price 1980).

\section{Arknowledgments}

We thank Frank Parker and Robert Fischel for assistance in collecting in costa Riea: owners and mantukers of Finca Bedlilat Ia Eunilia, and Finca Monte\%uma for permission to collect on the ir properties; Comzalo MoratBerja. D. Marcyues Macedo, $A$ de Somzal Landro, and V. Pereina da silva bunior for assistance in collectines in Brazil; and Tros Itciler for technical assistance. folun forster, Shripat Kimble, and Datid Stanley-Sannelson provided helpfinl suggestions and critical reviews of the mannseript. This sturly was partially funded by Trust

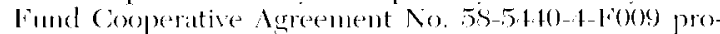
vided by the frood and Agriculture (Organization of the United Nations. This work was dene in cooperation with the Institute of Agriculture and Natural Resomerces, University of Vebrastit. I, incolu. and is published as foumal Series. Nebraskit Agricoultural Research Division palper $1057 \%$

\section{References Cited}

Bartlell, A. C., W. C. Randall, and J. F. May. 1983. Alloxime variation among populations of boll weerils in Arzona and Mexico. Sonthwest. Entomol. St: 11:130

Black, W. C., IV, and E. S. Krafour. 1985. Filectrophoretic analusis of gencetic variability in the loonse flo (Musca domestira 1.). Biochem. (irnet. 23: 19:3-20:3.
Catts, E. P., and N. I. Goff. 1992. Forensic entomologr in criminal investigations. Annu. Rev. Entomol. 37: 25:3-272.

Dear, J. P. 1985. A revision of the New World Chrvsomyini (1)iptera: Calliphoridac). Reve. Bras. Kool. 3: $109-169$.

Gmenberg, B. 1991. Flies as foremsic indicators. J. Med Entomol $28: 565-577$.

IIall, D. G. 1918. The blowflies of North Americal. Thomas Say forndation, vol. 4. lintomological Sorioty of America, I amblam, NI).

Iightower, B. (;., A. L. Adams, and D. A. Alley. 1965. Dispersal of releatsed imaldiated laboratoryreared screwworm flies. J. Ecom. Entomol. 5s: $33 ; 3-$ 37.4.

Krafour, F. S. 1993. Allomme variation in stable flies (Diptera: Muscidac). Biochesur. Conet. 31: 231-240.

Krafour, F. S., and W. C. Black IV. 1992. Analysis of isomme loci in the face Hu, Masca amtummalis DoGere. Biochem. Cenct. 30: 625-6.34.

Laake, E. W., E. C. Cushime, and II. E. Parish. 1936. Biolegy of the primaty serewworm fly, cochliomeia americana. and a comparison of its stages with those of C. macellaria. U.S. Dep. Agrie. Tecth. Bull. 500 .

Mayer, I). G., and M. G. Atzeni. 1993. Estimation of dispersal distances for Cochliemenia hominimorax (I)iptera: (alliphoridac). Einviron. Wintomol. 22: 368374 .

MrDonald, P. T., L. R. Hilhurn, and s. E. Kunz. 1987. Conetic sinulatities anomg natural populations of the hom fly (1)ipterat: Muscidate). Amo. Entomol. Soc. Ant. 80 ) $288-292$.

Munstermam, I. E. 1980. Distinguishing geographic: strains of the Aedes atropalpus group (Diptera: Culiceidae) by analysis of angme variation. Amm, Eistomol. Soc. Nin. 73: 699964

1984. Ceographic patterns of exencetic variation in the trectede mosquito Aede's triserialus. Pp. 327 - 343. In 1. P. I comtihos, I. R. Rov, and J. II. Framk /eds. I, Ecolog of mosrquitoes. Florida Medical Entomologr labl)oratory, Vico Batach

Murphy, R. W., J. W. Sites, Jr., D. (. Buth, and C. H. Haufler. 1900. Proteins I: iscoznone electrophoresis ple t5-126. In 1). M. Ilillis and (. Mority [orts.], Molorular svstematies. Sinamer, Sunderland, Mis

Nei, M. 1978. Estimation of ancrage heterosegesity and crenctic distance from a small mumber of individuals. Genetices 89: $5833-590$.

Nomenclature Committee International Inion of Biochemistry, 1981. Enzame nomenclature. Academic. New York

Irice, P. W. 1980. Exolutionary biology of parasites. Princetom University P'ress, Princeton, $\mathrm{N}$

slork, G. J. 1991. Biochenical systematics and population genetic structure of Anastrepha fraterculus and related species (1)iptera: Tephritidae). Ann. Entomol Soc. Ams. S4: 10 28

Strong, K. L., and R. J. Malhon. I991. Conetic vari-

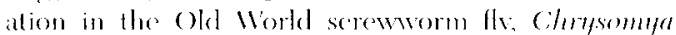
besiama (1)iptera: Calliphoridae). Bull. Entomol. lies. $81: 491-196$

Swofford, D. I., and R. B. Solander, 1981. BIOSYS I: a FORTRAN program for the comprehemsive andsis of electrophoretic data in population genetices and systematics, redeatse 1.7. I. Hered, 72: 2-281-283. 
Tabachnick, W. J., and J. R. Powell. 1979. A worldwide survey of genetic variation in the yellow fever mosquito, Aedes aegypti. Genet. Res. 34: 215-229.

Taylor, I. B., and R. D. Peterson II. 1994. Population genetics and gene variation in primary and secondary scremworm (1)iptera: ('alliphoridar). Ann. Entomol. Soc. Am. 87: 626-633.
Wright, s. 1978. Evolution and the genetics of populations, vol. 4. Variability within and annong natural populations. University of Chicago Press, (hicago.

Received for publication 26 October 1994: accepted 6 April 1995. 